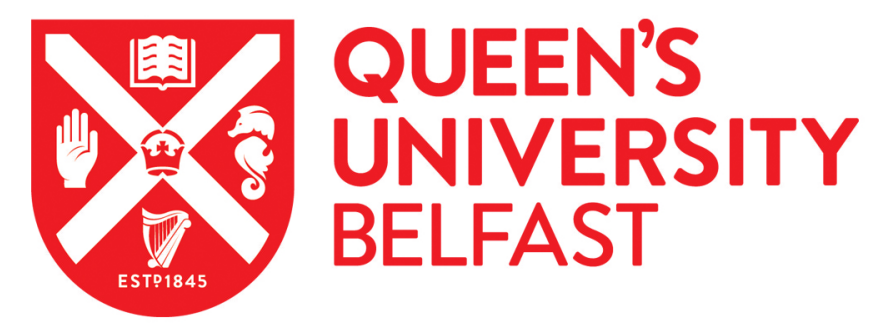

\title{
Development and Application of the Diffusive Gradients in Thin Films Technique for the Measurement of Nitrate in Soils
}

Cai , C., Williams, P. N., Li, H., Davison, W., Wei, T., Luo, J., Zhu, Y-G., \& Zhang, H. (2016). Development and Application of the Diffusive Gradients in Thin Films Technique for the Measurement of Nitrate in Soils. Analytical Chemistry. https://doi.org/10.1021/acs.analchem.6b03609

Published in:

Analytical Chemistry

Document Version:

Peer reviewed version

Queen's University Belfast - Research Portal:

Link to publication record in Queen's University Belfast Research Portal

Publisher rights

(C) 2016 ACS

\section{General rights}

Copyright for the publications made accessible via the Queen's University Belfast Research Portal is retained by the author(s) and / or other copyright owners and it is a condition of accessing these publications that users recognise and abide by the legal requirements associated with these rights.

Take down policy

The Research Portal is Queen's institutional repository that provides access to Queen's research output. Every effort has been made to ensure that content in the Research Portal does not infringe any person's rights, or applicable UK laws. If you discover content in the Research Portal that you believe breaches copyright or violates any law, please contact openaccess@qub.ac.uk. 
1 Development and application of the DGT technique for the 2 measurement of nitrate in soils

3 Chao Cai ${ }^{\mathrm{a}}$, Paul N. Williams ${ }^{\mathrm{a}, \mathrm{b}, \mathrm{c} *}$, Hong $\mathrm{Li}^{\mathrm{b}}$, William Davison ${ }^{\mathrm{b}}$, Tianjiao Wei ${ }^{\mathrm{d}}$, Jun Luo ${ }^{\mathrm{d}}$

4 Yong-Guan Zhu $^{\mathrm{a}^{*}}$, Hao Zhang ${ }^{\mathrm{b}, *}$

$5 \quad{ }^{a}$ Key Laboratory of Urban Environment and Health Institute of Urban Environment, Chinese

6 Academy of Sciences, Xiamen 361021, China

7 b Lancaster Environment Centre, Lancaster University, Lancaster LA1 4YQ, United Kingdom

$8 \quad{ }^{\mathrm{c}}$ Institute for Global Food Security, Queen's University Belfast, David Keir Building, Malone 9 Road, Belfast, BT9 5BN, Northern Ireland, UK.

d State Key Laboratory of Pollution Control of and Reuse, School of the Environment,

Nanjng University, Nanjing, Jiangsu, 210023.

*Corresponding authors

PNW. Telephone: +44-0-28-9097-6539. Email: p.williams@qub.ac.uk

HZ. Telephone: +44-0-1524-593899. Email: h.zhang@lancaster .ac.uk

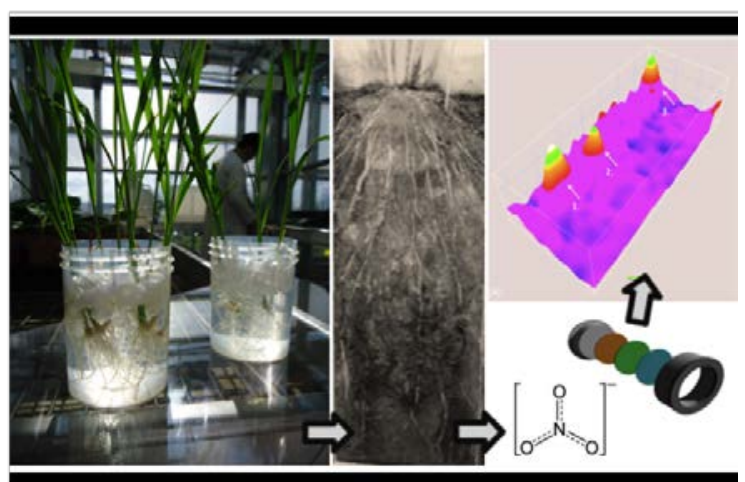

Graphic Abstract 


\section{ABSTRACT}

Nitrate $\left(\mathrm{NO}_{3}-\mathrm{N}\right)$, the main plant/microbial nitrogen source, has a fast turnover in soil driven by species transformation (nitrification/denitrification) and phyto/microbiota-assimilation. The technique of diffusive gradients in thin films (DGT) is capable of a robust, low disturbance measurement of $\mathrm{NO}_{3}-\mathrm{N}$, but it has not been implemented due to the absence of a binding layer suitable for deployment in soils. In this study a new, styrene divinylbenzene based absorbent with amine functional groups (SIR-100-HP) was cast into an agarose gel support. The $\mathrm{NO}_{3}-\mathrm{N}$ ion selectivity of the SIR-100-HP/agarose binding layer was retained in the presence of high multivalent ion concentrations and was used successfully to acquire in situ $\mathrm{NO}_{3}-\mathrm{N}$ measurements in bulk soil. The kinetics of binding and the maximum binding capacity were determined. The total capacity of the DGT containing the SIR-100-HP/agarose binding phase was $667 \mu \mathrm{g} \mathrm{NO}_{3}-\mathrm{N}$. The performance of DGT was not affected by varying $\mathrm{pH}$ (3-8) and ionic strength $\left(0-0.018 \mathrm{~mol} \mathrm{~L}^{-1}\right)$, while anion competition effects at concentrations reflecting those in common agricultural soils were found to be negligible. Complete elution (100\% efficiency) of $\mathrm{NO}_{3}-\mathrm{N}$ from the binding phase was achieved using a solution of $5 \%$

$\mathrm{NaCl}$. This technique was validated in three contrasting soils. $\mathrm{C}_{\text {DGT }}$ measurements were in excellent agreement with porewater $\mathrm{NO}_{3}-\mathrm{N}$ values. Two-dimensional $\mathrm{NO}_{3}-\mathrm{N}$ mapping of a profile of flooded rice paddy soil demonstrated the potential of this novel methodology for improved characterisation of in situ $\mathrm{N}$ speciation for further understanding of bioavailability and biogeochemical processes of $\mathrm{NO}_{3}-\mathrm{N}$ in soils.

\section{INTRODUCTION}

Nitrogen $(\mathrm{N})$, an essential mineral nutrient, is present in aerobic soil in several forms, with the oxyanion $\mathrm{NO}_{3}-\mathrm{N}$ being the primary species and hence the main available $\mathrm{N}$ source for plant/microbial growth. The $\mathrm{NO}_{3}-\mathrm{N}$ demand by crops is greater than the natural supply from 
most soils ${ }^{1,2}$. Typically plant tissue concentrations are $>1000$ times higher than that of their corresponding soil porewaters, therefore the diffusive supply of $\mathrm{NO}_{3}-\mathrm{N}$ to the roots is a major limiting factor for production yields ${ }^{1-3}$. In order to sustain and enhance crop production, $\mathrm{NO}_{3}-$ $\mathrm{N}$ fertilizers have been widely and heavily applied to agricultural soils, but $\mathrm{N}$-use efficiency remains low and over application of $\mathrm{N}$ fertilizers is common; an issue both of environmental and economic concern ${ }^{4-8}$.

Fertiliser applications to agricultural soils are largely determined by the measurements of the exchangeable $\mathrm{NO}_{3}-\mathrm{N}$ pool. Salt extractions such as $2 \mathrm{M} \mathrm{KCl}$ are the worldwide standard, but although of low cost, for many soils they provide a poor prediction of plant-N uptake ${ }^{9}$. Common difficulties associated with these assays include: i) a non-selectivity for $\mathrm{NO}_{3}-\mathrm{N}$, with the extraction also targeting all inorganic-N species. Therefore changes in speciation during sample collection, transfer, storage and analysis need to be considered. ii) a failing to encompass the rapid turnover of $\mathrm{NO}_{3}-\mathrm{N}$ in soil; a dynamic process governed by many factors including microbial/plant/redox mediated species change, biotic uptake and abiotic immobilisation ${ }^{10}$. Changes in the $\mathrm{NO}_{3}-\mathrm{N}$ pool with time are not accounted for by individual soil extraction measurements because only a single temporal time point is assessed. Furthermore, collection and processing of the soils invariably disturb the dynamics of the system and hence introduce additional measurement discrepancies. Transporting the collected field soils quickly to the laboratory is another consideration and challenge.

Quantitative determination of $\mathrm{NO}_{3}-\mathrm{N}$ concentrations can be achieved by other methods such as ion-selective electrodes (ISE), but even without considering the detector drift, problems with self-calibrations, a lack of sensitivity and selectivity (especially in complex soil matrixes), the development of organic films and biofouling on the sensors, the high set-up 
and running costs preclude these methods as a widespread soil screening tool. Further, the efficacy of ISE's in agricultural field soils has yet to be fully validated ${ }^{11}$.

In situ passive sampling techniques that collect analytes in a low disturbance/quantitatively well-defined manner such as DGT (Diffusive Gradients in Thin-films) can potentially overcome many of the limitations of both the salt extraction and ISE methods. The DGT measurement is an effective proxy/surrogate for plant uptake because it can successfully mimic the diffusive supply processes near root surfaces, while integrating a wider range of key soil properties that impact on release/adsorption than other single measurement approaches $^{12,13}$. Further, devices can be deployed cost effectively in sufficient numbers to obtain good spatial coverage, while critically in the case of $\mathrm{NO}_{3}-\mathrm{N}$ assessment, providing a time integrated measurement ${ }^{14}$. In situ deployment provides a more realistic measure of the soil $\mathrm{NO}_{3}-\mathrm{N}$ pool as any disturbance to the system during sampling is minimised.

A $\mathrm{NO}_{3}-\mathrm{N}$ selective DGT would greatly simplify the process of $\mathrm{N}$ measurement. The preconcentration of $\mathrm{NO}_{3}-\mathrm{N}$ by the DGT binding gel not only improves the sensitivity of the method, reduces measurement bias but also protects against $\mathrm{N}$-speciation changes associated with sample collection, transfer and storage. Very recently, a $\mathrm{NO}_{3}-\mathrm{N}$ DGT method based on a Purolite A520E anion exchange resin was developed for freshwaters ${ }^{15}$. However to date, there has been no validation of the method in soils, where the technique has perhaps it's most merit and yet is most challenged by interferences caused by competing ions. In the present study a new amine functionalised, styrene divinylbenzene, strong base anion exchange resin candidate was investigated for the development of a novel SIR-100-HP/agarose DGT and its suitability for $\mathrm{NO}_{3}-\mathrm{N}$ measurements in soils. 
MATERIALS AND METHODS

Apparatus and chemicals. The anion exchange resin (SIR-100-HP) was purchased from Resintech $^{\mathrm{TM}}$ (West Berlin, New Jersey, USA) and milled to a particle size of 200 mesh (Globe Mill, Retch, Germany). Agarose powder was bought from Fisher Scientific (UK). The other reagents were of analytical-reagent grade and were purchased from Sigma (USA). High-purity demineralized water (18.2 $\left.\Omega \mathrm{M} \mathrm{cm}^{-1}\right)$ provided by a Milli-Q (MQ) Plus filter apparatus (Millipore, USA) was used in this experiment.

Preparation of DGT. The presented method of preparing agarose gel is a modification of the procedure described by Docekalova \& Divis ${ }^{16}$ and Menegario et al. ${ }^{17}$. A diffusive gel containing $1.5 \%(\mathrm{~m} / \mathrm{v})$ agarose was prepared by dissolving the agarose in MQ water. The mixture was placed in an oven at $100^{\circ} \mathrm{C}$ for $2 \mathrm{hr}$ and gently stirred until all the agarose was dissolved. The hot gel solution was mixed well and immediately cast between two preheated glass plates $\left(100^{\circ} \mathrm{C}\right)$ separated by a $0.8 \mathrm{~mm}$ plastic spacer. The gel-mould was left to cool down to room temperature, and dismantled. Discs with a diameter of $2.5 \mathrm{~cm}$ were cut from the cooled gel and stored in MQ water.

A binding gel was prepared following a similar procedure, $4 \mathrm{~g}$ of resin (SIR-100-HP), drained of excess water, was transferred to a beaker with $11 \mathrm{ml}$ of $1.5 \%$ hot agarose solution. The solution with the resin was mixed vigorously to make sure the resin was fully dispersed. Then the solution was cast into the glass plate mould with $0.5 \mathrm{~mm}$ spacers and cooled at room temperature as described above for diffusive gels. (36

(1)

(1)


$\mathrm{NO}_{3}-\mathrm{N}$ determination. $\mathrm{NO}_{3}-\mathrm{N}$ was measured colorimetrically by a spectrophotometer

140 (Thermo Scientific) based on the Griess Reagent method according to Thabano et al. ${ }^{18}$. $\mathrm{NO}_{3}$ -

$\mathrm{N}$ was reduced to $\mathrm{NO}_{2}-\mathrm{N}$ using copper coated cadmium granules. This experimental step operated at $>95 \%$ efficiency. The $\mathrm{NO}_{2}-\mathrm{N}$ produced reacts with sulfanilamide solution, then the resulting solution is coupled with $\mathrm{N}$-(1-Naphtyl)-ethylemediamine dihydrochloride to form a coloured azo dye.

Kinetics and the Elution Efficiency of the Binding Gel. A binding layer (resin + gel support) must immobilise the target analyte effectively and efficiently in order to satisfy the requirements of the DGT principle. Mass balance experiments were conducted to investigate the kinetic properties of the binding gels for $\mathrm{NO}_{3}-\mathrm{N}$ over a time range spanning 1 min. to 24 hr. In each treatment, performed in triplicate, a gel disc was immersed in a $10 \mathrm{ml}$ solution of $50 \mathrm{mg} \mathrm{L}^{-1} \mathrm{NO}_{3}-\mathrm{N}$. The solutions were gently shaken continuously (SSL1 orbital, Stuart, at 50 rpm) with sub-samples collected before disc immersion and after retrieval.

$\mathrm{NO}_{3}-\mathrm{N}$ must be quantifiably and consistently eluted from the binding layer to enable analytical measurement. Mineral acids are the most common DGT eluents, but are not suitable for a $\mathrm{NO}_{3}-\mathrm{N}$ specific DGT because many of the methods for determining $\mathrm{NO}_{3}-\mathrm{N}$ are $\mathrm{pH}$ sensitive. $\mathrm{NaCl}$ is an effective ion exchange resin eluent ${ }^{19,20}$ of neutral $\mathrm{pH}$ and widely available at low cost. To optimise the elution of $\mathrm{NO}_{3}-\mathrm{N}$ from the gels, discs were immersed in $10 \mathrm{ml}$ of $10 \mathrm{mg} \mathrm{L}^{-1} \mathrm{NO}_{3}-\mathrm{N}$ for $20 \mathrm{hr}$, and then eluted for 4, 8, $20 \mathrm{hr}$ in $5 \mathrm{ml}$ of either $1 \%, 2 \%$, $3 \%$ or $5 \%(\mathrm{~m} / \mathrm{v}) \mathrm{NaCl}$.

Calculating DGT labile $\mathrm{NO}_{3}-\mathbf{N}$. The DGT solute concentration/activity (see equation 1) can be simply derived from 5 parameters. 
$\mathrm{C}_{\mathrm{DGT}}=M \times \Delta \mathrm{g} /(D \times A \times t) \quad$ (eq. 1)

166

The diffusive layer thickness $(\Delta g)$ and sampling window area $(A)$ are specific to the geometry of the DGT device, but consistent amongst samplers.

169

Diffusion coefficient (D). As no published diffusion coefficient for $\mathrm{NO}_{3}-\mathrm{N}$ in agarose gel was available this had to be experimentally determined. This was achieved using a previously described diffusion cell ${ }^{21}$, which consisted of two compartments (A and B) joined by a $1.5 \mathrm{~cm}$ diameter circular connecting window. A $0.8 \mathrm{~mm}$ thick diffusive gel was placed across the window and the sections secured with clips. Compartment A was filled with $50 \mathrm{ml}$ of $200 \mathrm{mg}$ $\mathrm{L}^{-1} \mathrm{NaNO}_{3}$ solution and compartment $\mathrm{B}$ was filled with MQ water. The solution in each compartment/section was well stirred during the experiments. Subsamples $(1 \mathrm{ml})$ were collected every $10 \mathrm{~min}$. over a time series, ranging from 30 to $120 \mathrm{~min}$.. The diffusion coefficient was calculated from the slope of the linear plot of the mass of $\mathrm{NaNO}_{3}$ in compartment B versus time. sampling time point, three DGT units were collected for analysis.

Mass (M). Binding layers have a finite capacity, which governs the DGT performance. 
were deployed in a series of solutions with different $\mathrm{NO}_{3}-\mathrm{N}$ concentrations, spanning a concentration range from 0 to $240 \mathrm{mg} \mathrm{L}^{-1}$ for $4 \mathrm{hr}$. Each concentration treatment was performed in triplicate.

\section{Characteristics of DGT performance in solutions.}

Standard piston-type DGT holders with a $2 \mathrm{~cm}$ diameter exposure window (DGT Research Ltd.) were used for the DGT devices. A $0.5 \mathrm{~mm}$ thick binding gel was placed on the bottom of the holder, which was covered in order by a $0.8 \mathrm{~mm}$ thick diffusion gel and a $0.13 \mathrm{~mm}$ thick cellulose filter membrane (Whatman, $0.45 \mu \mathrm{m}$ pore size). Unless otherwise stated all the tests were carried out in a deployment tank containing $2.8 \mathrm{~L}$ of $50 \mathrm{mg} \mathrm{L}^{-1} \mathrm{NO}_{3}-\mathrm{N}$ solution and eluted in $5 \% \mathrm{NaCl}(\mathrm{m} / \mathrm{v})$ for $8 \mathrm{hrs}$.

DGT Detection Limits, were calculated as three times the standard deviation of the DGT blanks (gels used in the devices were derived from the same gel batches used for the DGT experiments) ( $\mathrm{n}=12)$. Blank analyses were assessed as follows: DGT devices (three replicates per experiment) were assembled and placed in a deployment tank with $2.8 \mathrm{~L} \mathrm{MQ}$ water for $4 \mathrm{hr}$.

Effect of pH and Ionic Strength. In order to investigate the effect of pH on DGT responses, DGT assemblies were immersed in $\mathrm{NaNO}_{3}$ solutions prepared to cover a $\mathrm{pH}$ range from 3.1 to 8.1. The $\mathrm{pH}$ of the solutions was adjusted using dilute $1 \% \mathrm{H}_{2} \mathrm{SO}_{4}(\mathrm{v} / \mathrm{v})$ or $2 \mathrm{~mol} \mathrm{~L}^{-1}$ $\mathrm{NaOH}$. To test DGT performance at low ionic strengths, DGT assemblies were exposed to $\mathrm{NaNO}_{3}$ solution with appropriate additions of $\mathrm{Na}_{2} \mathrm{SO}_{4}$ to give an ionic strength range of 0 to $0.018 \mathrm{~mol} \mathrm{~L}^{-1}$. For both deployment campaigns ( $\mathrm{pH}$ and ionic strength) and at each treatment, three SIR-100-HP/agarose DGT devices were deployed in two separate time series 
experiments (4 and $24 \mathrm{hr}$ ), one following the standard DGT testing procedure and the other for being consistent with the soil deployment time of $24 \mathrm{hr}$.

Competition. The effect of potential competitive anions in solutions at concentrations that reflect the porewater of most common soils was studied ${ }^{22}$. DGT devices (in triplicate) were deployed separately for both 4 and $24 \mathrm{hr}$ in various well stirred solutions containing both 50 mmol L ${ }^{-1} \mathrm{NaNO}_{3}$ and: (a) no other amendment/control, (b) $\mathrm{Cl}^{-}\left[250 \mathrm{mg} \mathrm{L}^{-1}\right.$, (c) $\mathrm{NO}_{2}-\mathrm{N}$ [1 mg $\left.\mathrm{L}^{-1}\right]$, (d) $\mathrm{CaCO}_{3}\left[13 \mathrm{mg} \mathrm{L}^{-1}\right]$, (e) $\mathrm{HCO}_{3}^{-}\left[50 \mathrm{mg} \mathrm{L}^{-1}\right]$, (f) $\mathrm{HPO}_{4}{ }^{2-}\left[10 \mathrm{mg} \mathrm{L}^{-1}\right]$.

\section{Characteristics of DGT performance in soils.}

Three contrasting agricultural soils $(0-20 \mathrm{~cm}$ depth), two from the UK and one from South China were tested. The two soils from the UK have been characterized previously ${ }^{23,24}$, the first being a humic rendzina with a clay loam texture (Rendzina) and the second a brown sandy loam (Brown sand). The final sample was a clay/silt paddy soil (Paddy soil). Prior to DGT deployment the soils were air-dried and then passed through a $2 \mathrm{~mm}$ sieve to ensure homogeneous soil samples for comparison of porewater and DGT-measured concentrations.

For DGT deployment, $80 \mathrm{~g}$ of each air-dried soil sample was brought to $60 \%$ maximum water holding capacity (MWHC) and incubated for 2 days. The moisture content was then raised to 80\% MWHC for $24 \mathrm{hr}^{13}$. DGT devices (n=3) were placed on the soil paste and twisted gently a few times to ensure complete contact between the filter membrane of the device and the soil. They were deployed for $20 \mathrm{hr}$ at $16.5^{\circ} \mathrm{C}$. 
239 On retrieval, DGT devices were jet-washed with MQ water to remove soil particles and then 240 disassembled. The binding gels were removed from the DGT device and immersed in $10 \mathrm{~mL}$ 241 of $5 \% \mathrm{NaCl}(\mathrm{m} / \mathrm{v})$ for at least $8 \mathrm{hr}$ prior to analysis. After completing the DGT deployments, 242 soil solution was collected by centrifuging the soil at $5000 \mathrm{~g}$ for $15 \mathrm{~min} .{ }^{23}$. The supernatants 243 were filtered through a $13 \mathrm{~mm}$ diameter, $0.45 \mu \mathrm{m}$, polysulfone filter. Total concentrations of $244 \mathrm{NO}_{3}-\mathrm{N}$ in DGT elutes and in soil pore water were determined by using the method stated previously.

246

\section{Two dimensional mapping of $\mathrm{NO}_{3}-\mathrm{N}$ distribution in paddy soil}

In this experiment perspex rhizotrons with removable front plates ${ }^{25,26}$ (inner dimensions. HxWxD: 40x20x3cm) were filled with dry, sieved $(<2 \mathrm{~mm})$ paddy soil, which was set in layers to achieve an even soil structure. Soils were carefully re-wetted with a water spray until saturation. A nuclepore membrane $(0.2 \mu \mathrm{m}$ pore size, thickness $\sim 10 \mu \mathrm{m})$ then overlaid the soil, and was secured to the outer walls of the rhizotron with water-proof tape. A rice seedling was transplanted into the rhizotron and the whole system was transferred into a water tank in the greenhouse for three months. The spatial heterogeneity of $\mathrm{NO}_{3}-\mathrm{N}$ distribution in soil would have been developed with time due to biogeochemical processes in both bulk soil and in the rhizosphere. At grain maturation, a 12.5 x $6.5 \mathrm{~cm} \mathrm{NO}-\mathrm{N}$ DGT was deployed within the root zone, attached to the inner-side of the detachable front plate of the rhizotron with waterproof tape. Ingress of oxygen into the anaerobic soils was minimal during deployment as this operation was performed in aquarium water that had previously been deoxygenated with nitrogen.

After deployment, the $\mathrm{NO}_{3}-\mathrm{N}$ DGT was rinsed with MQ water, cut into $5 \mathrm{x} 5 \mathrm{~mm}$ squares and transferred into $1.5 \mathrm{ml}$ micro-centrifuge tubes. Gel pieces were eluted in $1 \mathrm{ml} 5 \% \mathrm{NaCl}$ and 
shaken for $8 \mathrm{hr}$ at room temperature. The samples were then centrifuged at $5000 \mathrm{~g}$ for $5 \mathrm{~min}$. and the recovered solutions transferred to $15 \mathrm{ml}$ tubes and diluted 6 times. $\mathrm{NO}_{3}-\mathrm{N}$ concentrations were analyzed by flow injection analysis (Manufacturer: Lachat Inc., USA).

\section{RESULTS AND DISCUSSION}

\section{Kinetic performance of the SIP-100-HP binding gel}

Figure 1a demonstrates the adsorption of $\mathrm{NO}_{3}-\mathrm{N}$ by the resin gel with time. The initial steepness of the uptake curve (0-10 min.) demonstrates that binding is sufficiently rapid to ensure the $\mathrm{NO}_{3}-\mathrm{N}$ concentration at the resin surface is effectively zero. The resin was able to scavenge all the $\mathrm{NO}_{3}-\mathrm{N}$ from the solution, accumulating more than $50 \%$ of the total mass within 30 min. of immersion. The maximum amount of $\mathrm{N}$ accumulated by a DGT device in a 60 sec. deployment time can be calculated for a solution of $50 \mathrm{mg} \mathrm{L}^{-1}$; a typical solution concentration employed in performance testing ${ }^{27}$. The result shows that the amount theoretically taken-up by DGT $\left(1.2 \times 10^{-3} \mathrm{mg}\right)$ is less than the amount of $\mathrm{N}$ taken up by the resin gel in the kinetic experiment for the same 60 sec. time period (Figure 1a and b). The binding rate is therefore more than sufficient to satisfy the DGT demand.

\section{Elution efficiency}

In addition to having both a high and consistent elution efficiency ${ }^{28}$, the eluting solution for the DGT binding phase elutes needs to be safe to work with, cost effective, and not interfere with the analytical measurement. A series of experiments demonstrate $\mathrm{NaCl}$ to be an excellent candidate elute for a SIP-100-HP/agarose binding layer, fulfilling all the above criteria. Table 1. shows the effect of $\mathrm{NaCl}$ concentration $(1-5 \% \mathrm{~m} / \mathrm{v})$ and extraction time (4$20 \mathrm{hr}$ ) on the elution efficiency. In summary, the recovery of $\mathrm{NO}_{3}-\mathrm{N}$ increased both with increasing eluent concentration and/or elution time, with complete desorption of the SIP-100- 
HP bound $\mathrm{NO}_{3}-\mathrm{N}$. In a compromise between elute concentration and extraction time, the optimal method finally adopted, for all the further experiments, was a $5 \% \mathrm{NaCl}(\mathrm{m} / \mathrm{v})$ solution with gel being eluted for $8 \mathrm{hr}$.

\section{DGT blanks and detection limits}

The regression line from the calibration data for the $\mathrm{NO}_{3}-\mathrm{N}$ measurements were used directly to calculate the limit of detection $\left(\mathrm{C}_{\mathrm{LOD}}\right)$ and quantification $\left(\mathrm{C}_{\mathrm{LOQ}}\right)$, according to eq. $(2)$ and (3) respectively. Where $S_{i}$ was calculated from the standard deviation of the $y / x$ intercept and $\mathrm{b}$ the slope.

8

9

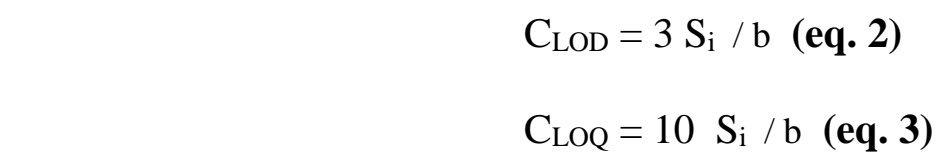

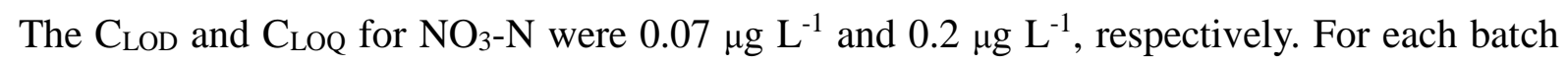
of binding layers synthesised and used in the DGTs, a blank measurement was made to monitor the possible contamination during experiment process. As DGT is an accumulation technique, the method detection limit (MDL) varies with deployment time and solution concentration. For this study, binding gel blanks were collected and the method detection limit (MDL) of the DGT technique was calculated as three times the standard deviation of the blank value. The average MDLs achieved in the laboratory experiments for a DGT deployment of 4 hr and 1 day were $3.9 \mu \mathrm{g} \mathrm{L}{ }^{-1}, 0.7 \mu \mathrm{g} \mathrm{L} \mathrm{L}^{-1}$, respectively. The method precision for DGT's deployed in solutions $(n=6)$ of $\mathrm{NaNO}_{3}$ for $4 \mathrm{hr}$ were $<3 \%$. 
Diffusion Coefficient in the gel

The masses of $\mathrm{NO}_{3}-\mathrm{N}$ that diffused from compartment $\mathrm{A}$ of the diffusion cell to compartment

$\mathrm{B}$, through the agarose gel with time were positively correlated (regression coefficient, 0.98)

(Figure 2a),. Diffusion coefficients, D, for $\mathrm{NO}_{3}-\mathrm{N}$ were calculated using eq. $4^{29}$. For a temperature of $24^{\circ} \mathrm{C}$, D equalled $11.1 \times 10^{-6} \mathrm{~cm}^{2} \mathrm{~s}^{-1}$. Where $\mathrm{s}$ is the slope of the regression line derived from mass vs. time, and $\mathrm{C}$ is the $\mathrm{NO}_{3}-\mathrm{N}$ concentration in compartment $\mathrm{A}$ (source compartment). The diffusion coefficients for the temperature series 1 to $35^{\circ} \mathrm{C}$ are provided in Table S1 (Supporting Information).

$$
\mathrm{D}=\mathrm{s} \Delta \mathrm{g} /(\mathrm{CA})
$$
experiments.

\section{Capacity of DGT}

There is a potential for the binding gel to become saturated because of the high accumulation of analytes when the measurement is performed over the long-term (weeks or months) or in environmental matrixes with high analyte concentrations. The DGT capacity may thus be a limiting factor for such applications. A linear and theoretically predictable response was obtained with deployment solution concentrations up to $120 \mathrm{mg} \mathrm{L}^{-1} \mathrm{NO}_{3}-\mathrm{N}$ for 4 hr (Figure 
from the known solution concentrations. The linear response between accumulated mass by DGT and the increasing solution concentrations showed that the capacity of a single DGT device is $667 \mathrm{mg} \mathrm{NO}_{3}-\mathrm{N}$, thereby validating the quantitative use of DGT below mass loading of $377 \mathrm{mg} \mathrm{cm}^{-2}$. This is comparable to the capacity of the only other $\mathrm{NO}_{3}-\mathrm{N}$ DGT.

\section{Effect of deployment time}

According to DGT theory, the mass of analyte accumulated by DGT devices should increase linearly with time, providing the capacity of the adsorbent has not been exceeded and the uptake kinetics are rapid enough to ensure the concentration of analyte at the interface between the binding gel and diffusive gel is zero. In this study, the mass of $\mathrm{NO}_{3}-\mathrm{N}$ loaded onto the binding gel increased linearly in a deployment solution of $50 \mathrm{mg} \mathrm{L}^{-1} \mathrm{NO}_{3}-\mathrm{N}$, with time within $36 \mathrm{hr}$ and fitted the theoretical line calculated from the known solution concentrations (Figure 1b). However, the accumulated mass deviated below the theoretical line at $48 \mathrm{hr}$ (Figure 1b) as the accumulated amount was close to the capacity limit.

\section{Effect of pH}

The effect of $\mathrm{pH}$ on the DGT performance is demonstrated by the ratio of DGT measured $\mathrm{NO}_{3}-\mathrm{N}$ to actual concentration in solution (Table 2). The ratio of $\mathrm{NO}_{3}-\mathrm{N}$ varied between a minimum of 0.9 and a maximum of 1.1 when the $\mathrm{pH}$ changed from 3.1 to 8.1 , which is within acceptable performance parameters for DGT measurements and in agreement with other commonly used resin layers ${ }^{31,32}$. Rarely is the $\mathrm{pH}$ of a soil outside this range so $\mathrm{pH}$ limitations are not a significant consideration with this new method.

\section{Effect of ionic strength}

In soil solution/porewaters, ionic strength and composition can vary greatly. To evaluate the 
effect of ionic strength on operational performance, the DGT assemblies were exposed to test solutions containing $10 \mathrm{mg} \mathrm{L}^{-1} \mathrm{NO}_{3}-\mathrm{N}$ over a range of ionic strengths $\left(0-36 \mathrm{mmol} \mathrm{L}^{-1}\right)$. Table 2 shows the ratio between the DGT measured $\mathrm{NO}_{3}-\mathrm{N}$ against the $\mathrm{NO}_{3}-\mathrm{N}$ concentration in solution. At ionic strengths of $0.3,3,9$ and $18 \mathrm{mmol} \mathrm{L}^{-1}$, DGT measurements agreed well with the actual concentrations in the deployment solutions (Table 2). Whereas a lower DGT measurement was found at ionic strengths of $36 \mathrm{mmol} \mathrm{L}^{-1}$, as the ratio of $\mathrm{C}_{\mathrm{DGT}}$ to $\mathrm{C}_{\text {soln }}$ decreased to $0.78 \pm 0.02$. To place this in perspective, it is commonplace in many soil studies to use $5 \mathrm{mmol} \mathrm{L}^{-1} \mathrm{Ca}^{2+}$ solutions for equilibration with soil to mimic typical soil pore water ionic strength and composition ${ }^{33}$.

\section{Competition Effects}

To test the potential competition effects from the major anions in soil solution and how they impact on $\mathrm{NO}_{3}-\mathrm{N}$ DGT performance, different exposure scenarios designed to reflect environmentally relevant conditions were trialled. The results (Table 2) showed that the impact on DGT performance from potentially competing anions is likely to be negligible in typical soil porewaters. ANOVA analysis, revealed no statistically significant difference (p > 0.05) between the concentrations measured in the control and the other anion treatments. Furthermore, all the $\mathrm{C}_{\mathrm{DGT}} / \mathrm{C}_{\text {soln }}$ ratios were generally in the range 0.90 to 1.10 , which is considered acceptable for DGT measurements (Table 2 ). However, some elements in natural media vary extensively. Concentrations of $\mathrm{Cl}^{-}$in some extreme case, such as alkaline saline soils, can for example exceed $500 \mathrm{mg} \mathrm{L}^{-1}{ }^{34}$. When the $\mathrm{NO}_{3}-\mathrm{N}$ DGT was trialled in deployment solutions of $500 \mathrm{mg} \mathrm{L}^{-1}$, binding efficiency was slightly impaired causing the $\mathrm{C}_{\mathrm{DGT}} / \mathrm{C}_{\text {soln }}$ to decline from $0.99 \pm 0.02$ (at $250 \mathrm{mg} \mathrm{NO}_{3}{ }^{-} \mathrm{L}^{-1} ; 4 \mathrm{hr}$ deployment) to $0.90 \pm 0.03$. When $\mathrm{HPO}_{4}{ }^{2-}$ exceed $25 \mathrm{mg} \mathrm{L}^{-1}$, which is comparably infrequent ${ }^{3}$, the ratio of $\mathrm{C}_{\mathrm{DGT}} / \mathrm{C}_{\text {soln }}$ fell to 0.71 ( 4 hr deployment, Table 2). These results suggest that there is competition between 
$\mathrm{NO}_{3}-\mathrm{N}$ and other ions in solution for binding sites on the binding resin under extreme conditions.

\section{Application in soils}

DGT devices were deployed in three types of soils for $20 \mathrm{hr}$. The concentrations of $\mathrm{NO}_{3}-\mathrm{N}$ in DGT elution and soil solution were determined. DGT measured concentrations, $\mathrm{C}_{\text {DGT, }}$ were calculated from the mass of $\mathrm{NO}_{3}-\mathrm{N}$ accumulated using equation 1 . The $\mathrm{C}_{\text {DGT }}$ measurements were in good agreement ( $<10 \%$ error) with those for $\mathrm{C}_{\text {soln }}$ (Table 2), indicating $\mathrm{NO}_{3}-\mathrm{N}$ supply is well buffered. Nitrate transfer from porewater to the SIR-100-HP/agarose DGT devices, follows the same principals that govern all DGT measurements. However, interpretation of the change in solute concentration in the porewaters as $\mathrm{NO}_{3}-\mathrm{N}$ is continuously removed by the DGT samplers, differs slightly from that of other elements/species. This is because desorption of $\mathrm{NO}_{3}{ }^{-} \mathrm{N}$ from binding sites on the soil-solid phase is less important in reestablishment of equilibrium, than is typical for other moieties. Nitrate is not readily retained by soil particles, unless they possess a positive charge (e.g. low pH soils) ${ }^{22}$. Therefore, the $\mathrm{NO}_{3}-\mathrm{N}$ reserve/store available for exchange, in the majority of unfertilised soils is relatively small, deriving primarily from amino acids bound to soil particle surfaces ${ }^{35}$. Mineralisation, the microbial conversion of organic- $\mathrm{N}$ to mineral- $\mathrm{N}$, therefore contributes more to the solute supply flux, and hence controls the buffering characteristics of the soil. Mineralization rates are highest in warm, moist, organic soils ${ }^{22}$. The next method development step, would be the validation of SIR-100-HP/agarose DGT either in-situ or on moist, field soils cored and preserved for analysis in the laboratory, as robust predictors of plant uptake/tissue content; as is the case for using DGT to predict bioavailable $\mathrm{P}^{36}$ and trace metals in plants ${ }^{13}$. 


\section{Mapping of the distribution of DGT labile $\mathrm{NO}_{3}-\mathrm{N}$ in a paddy soil}

To extend the application of DGT in soils, a two-dimensional distribution of labile $\mathrm{NO}_{3}-\mathrm{N}$ in a paddy soil was obtained. Clear spatial heterogeneity in DGT measured $\mathrm{NO}_{3}-\mathrm{N}$ are illustrated (Figure 3). In the bulk of the soil sampled, $\mathrm{NO}_{3}-\mathrm{N}$ fluxes were low at $20 \mathrm{pg} \mathrm{cm}^{-2} \mathrm{~s}^{-}$ ${ }^{1}$,but the 3 microniche zones with maxima ca. 4-fold higher, were also observed. It is inconclusive, whether these geochemical features arose due to plant root influence, microbial activity or abiotic factors. With nitrogen remaining the most important limiting nutrient for plant growth ${ }^{7}$ there is great potential in applying the 2D DGT chemical imaging methods to characterise $\mathrm{NO}_{3}-\mathrm{N}$ availability simultaneously with other elements (nutrients/toxins) for further understanding of uptake efficiency, which would assist plant breeding programmes and improve the selection of cultivar's with optimised ionomes ${ }^{25,26}$. Combing the presented $\mathrm{NO}_{3}-\mathrm{N}$ DGT with new developments in DGT for $\mathrm{NH}_{4}-\mathrm{N}$ affords the opportunity to further develop in situ nitrogen speciation measurement/mapping ${ }^{27,38}$..

We have demonstrated that $\mathrm{NO}_{3}-\mathrm{N}$ in soil porewaters can be measured in a quantative manner using standard DGT devices fitted with a SIP-100-HP/agarose binding layer. One-hundred percent elution efficiencies can be obtained without the need for hazardous mineral acids in a simple procedure using only $\mathrm{NaCl}$ solution, while the analysis can be completed easily with a standard spectrophotometer. The cost effectiveness of the technique allows deployment in sufficient numbers to obtain a good spatial coverage, while simultaneously providing a timeintegrated measurement. The adsorption kinetics, selectivity and capacity of the SIP-100-HP binding layer met the prequisites for use in DGT and have been shown to be sufficient for deployment in normal soil conditions, and validated in three different soils (humic rendzina, brown sand, and rice paddy soil). Preliminary results for $2 \mathrm{D}$ measurements of $\mathrm{NO}_{3}-\mathrm{N}$ in soil clearly show the potential for the DGT technique to be used in chemical imaging applications 
439 for further understanding of bioavailability and biogeochemical processes of $\mathrm{NO}_{3}-\mathrm{N}$ in soils ${ }^{26}$

Acknowledgements

444

This study received support from the Newton Fund/Royal Society (R1504GFS), NFSC (21511130063 and 41571130063) the CAS-PIFI award (2016VEC001).

446

\section{Supporting Information}

448 Additional information as noted in the text. This material is available free of charge via the 449 internet at http://pubs.acs.org

450

451

455

456 
Figure 1. a) Kinetics of $\mathrm{NO}_{3}-\mathrm{N}$ adsorption by SIP-100-HP binding gel. Error bars are calculated from the standard deviation of replicates $(n=3)$. b) Mass of $\mathrm{NO}_{3}-\mathrm{N}$ accumulated by DGT devices placed in solutions containing $50 \mathrm{mg} \mathrm{L}^{-1} \mathrm{NO}_{3}-\mathrm{N}$. Error bars are calculated from the standard deviation of triplicates.

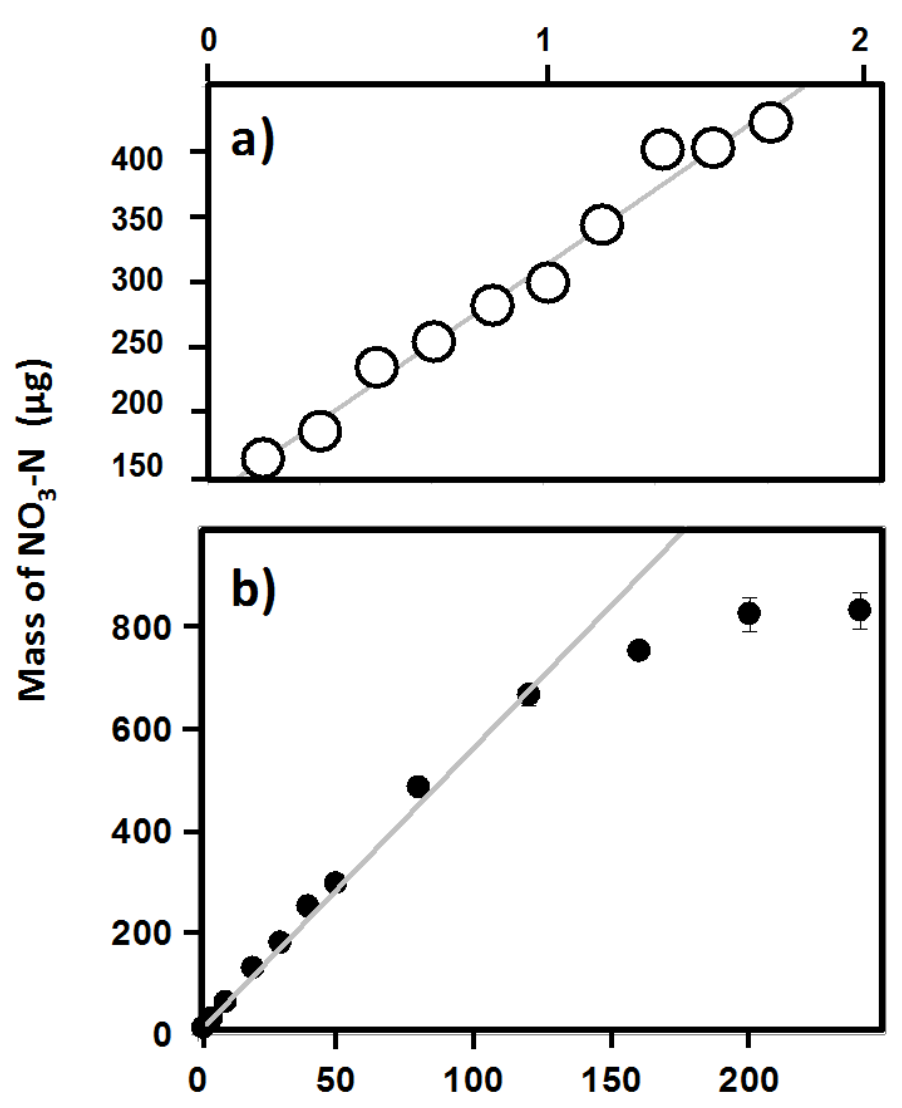

$\mathrm{NO}_{3}-\mathrm{N}$ in solution $\left(\mathrm{mg} \mathrm{L}^{-1}\right)$

\section{Time (hr)}




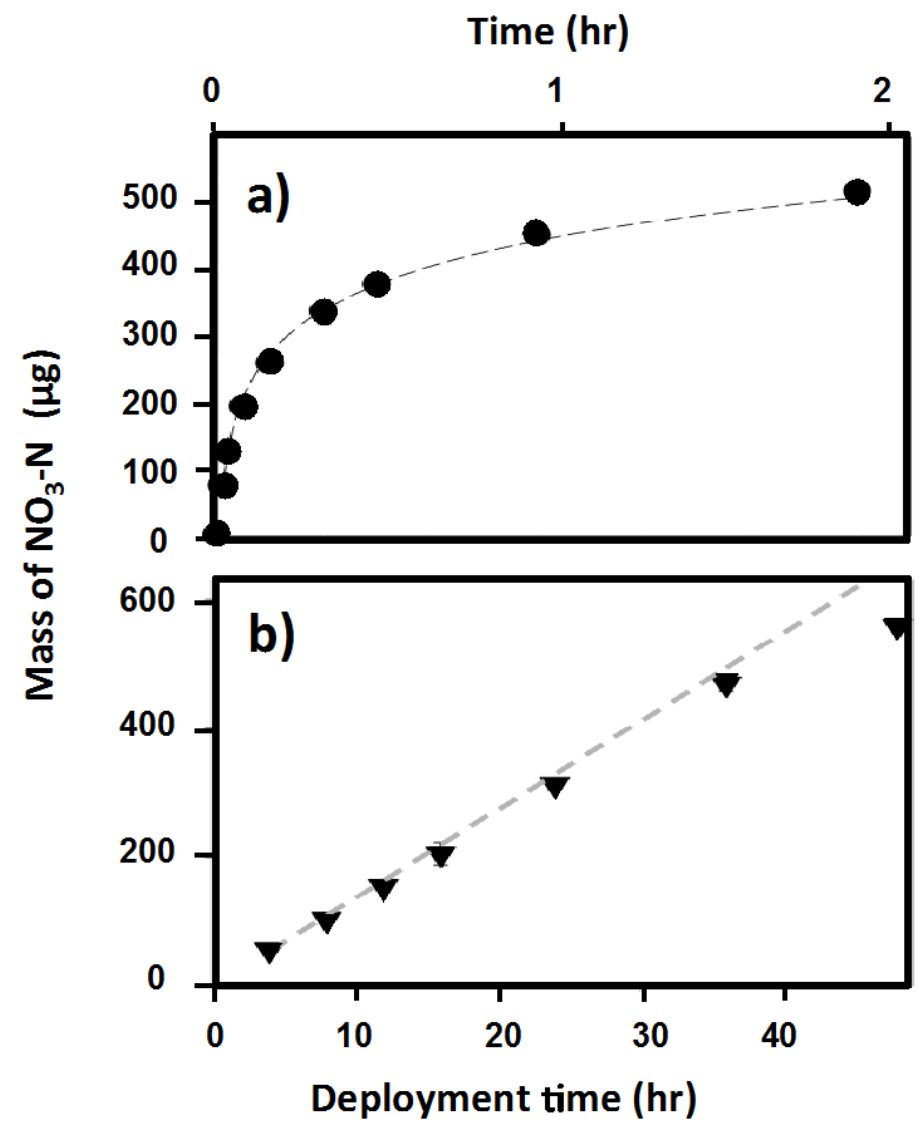

Figure 2. a) Plot of mass of $\mathrm{NO}_{3}-\mathrm{N}$ sampled from compartment $\mathrm{B}$ vs time in the diffusion cell experiment at $25^{\circ} \mathrm{C}$. The correlation coefficient between mass and time was 0.98 . b) Dependence of mass of nitrate accumulated by DGT for the binding gel on solution concentration. The line is the theoretical slope calculated from known concentrations in solution. The grey solid line was calculated from independently measured solution concentrations according to the equation $\mathrm{C}=M \mathrm{~g} / D A t$. 

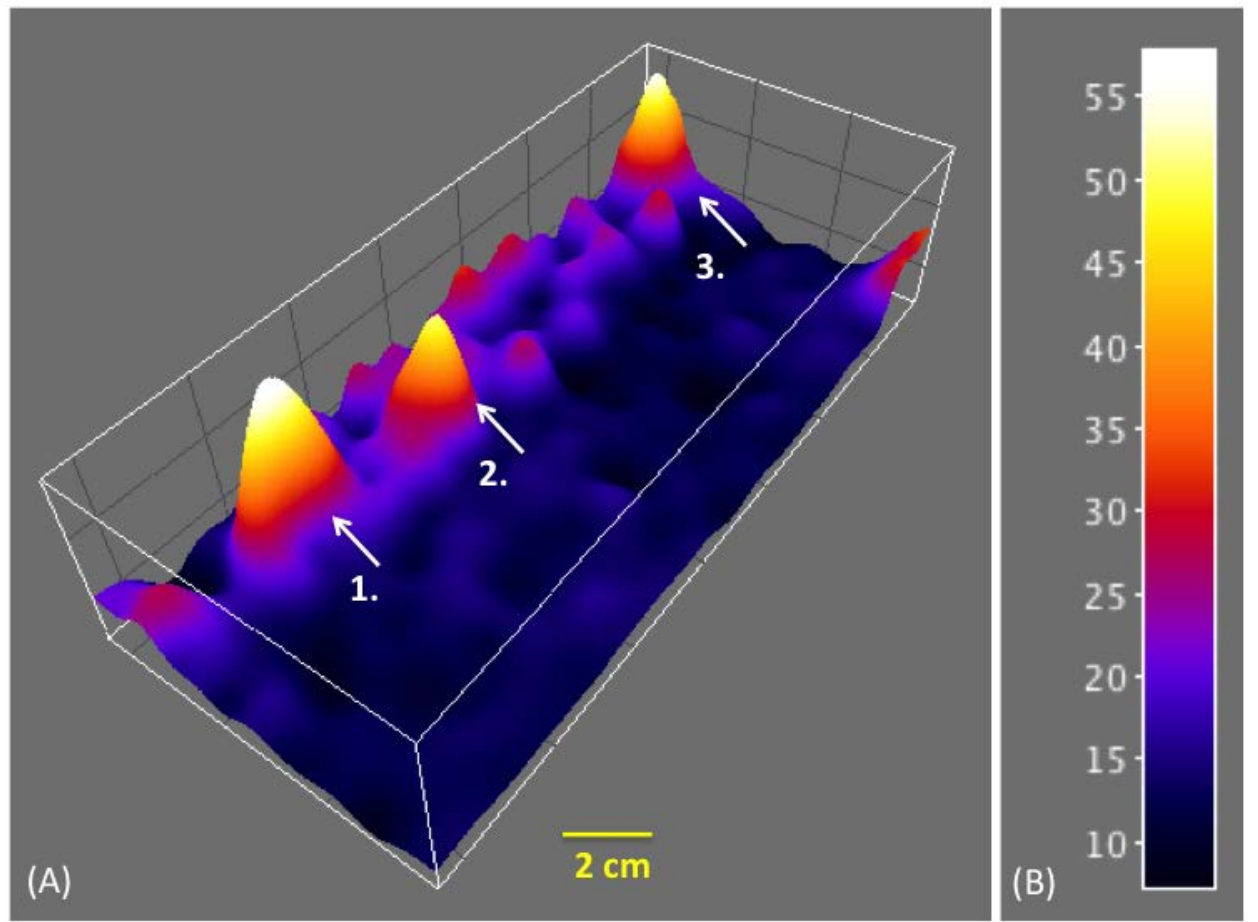

Figure 3. 2D mapping of $\mathrm{NO}_{3}-\mathrm{N}$ fluxes in a paddy soil. (A) Profile view of flux measurements, points 1-3 denote microniches/hot spots of enhanced $\mathrm{NO}_{3}-\mathrm{N}$ mobilisation. (B) The dark-blue to white colour scale represents a sequential increase in $\mathrm{NO}_{3}-\mathrm{N}$ fluxes ( $\mathrm{pg} \mathrm{cm}^{-2}$ $\left.\mathrm{s}^{-1}\right)$. 
Table 1. Optimisation of nitrate elution from SIR-100-HP DGT. Two-factor factorial design, $\mathrm{NaCl}$ solution concentrations (\% m/v) with different elution times (hr).

\begin{tabular}{lllll}
\hline Elution Time & $1 \% \mathrm{NaCl}$ & $2 \% \mathrm{NaCl}$ & $3 \% \mathrm{NaCl}$ & $5 \% \mathrm{NaCl}$ \\
\hline $4 \mathrm{hr}$ & $0.78 \pm 0.009$ & $0.86 \pm 0.007$ & $0.91 \pm 0.007$ & $0.93 \pm 0.005$ \\
$8 \mathrm{hr}$ & $0.87 \pm 0.014$ & $0.96 \pm 0.018$ & $0.97 \pm 0.013$ & $1.02 \pm 0.019$ \\
$20 \mathrm{hr}$ & $0.87 \pm 0.006$ & $0.96 \pm 0.009$ & $1.01 \pm 0.006$ & $1.04 \pm 0.002$ \\
\hline
\end{tabular}


Table 2. Competition Effects and Applications in Soil. A) Effect of $\mathrm{pH}$ on the ratio of concentrations of $\mathrm{NO}_{3}-\mathrm{N}$ measured by DGT, $C_{\text {DGT }}$, to deployment solution concentrations, $C_{\text {soln. }} B$ ) Effect of concentration of supporting electrolyte, $\mathrm{Na}_{2} \mathrm{SO}_{4}$, on the ratio of $C_{\text {DGT }} / C_{\text {soln. }}$. C) different anions; $\mathrm{Cl}^{-}, \mathrm{NO}_{2}-\mathrm{N}, \mathrm{CaCO}_{3}, \mathrm{HPO}_{4}{ }^{2-}$, D) $C_{\mathrm{DGT}}$, to soil solution concentrations.

\begin{tabular}{|c|c|c|c|c|c|}
\hline & \multicolumn{2}{|c|}{$\begin{array}{l}4 \text { hr Deployment } \\
\text { CDGT / C Soln }\end{array}$} & \multicolumn{3}{|c|}{$\begin{array}{c}24 \text { hr Deploymen } \\
\text { CDGT / C Soln }\end{array}$} \\
\hline & \multicolumn{2}{|c|}{ Average Stdev. } & Average & & Stdev. \\
\hline \multirow[t]{7}{*}{ A) } & \multicolumn{5}{|c|}{$p H$} \\
\hline & 1.06 & \pm 0.02 & 1.01 & \pm & 0.06 \\
\hline & 1.09 & \pm 0.02 & 1.03 & \pm & 0.04 \\
\hline & 1.09 & \pm 0.03 & 0.98 & \pm & 0.04 \\
\hline & 1.07 & \pm 0.03 & 1.05 & \pm & 0.01 \\
\hline & 1.10 & \pm 0.03 & 0.98 & \pm & 0.06 \\
\hline & 1.09 & \pm 0.02 & 1.03 & \pm & 0.07 \\
\hline \multirow[t]{7}{*}{ B) } & \multicolumn{5}{|c|}{ I ONIC STRENGTH $(\mathrm{mM})$} \\
\hline & 1.01 & \pm 0.03 & 0.93 & \pm & 0.03 \\
\hline & 1.05 & \pm 0.01 & 0.91 & \pm & 0.05 \\
\hline & 1.06 & \pm 0.01 & 0.97 & \pm & 0.02 \\
\hline & 1.02 & \pm 0.03 & 0.95 & \pm & 0.08 \\
\hline & 0.92 & \pm 0.02 & 0.96 & \pm & 0.02 \\
\hline & 0.78 & \pm 0.02 & $\sim$ & \pm & $\sim$ \\
\hline C) & \multicolumn{5}{|c|}{ ANION COMPETITION } \\
\hline Control & 1.01 & \pm 0.04 & 0.89 & \pm & 0.04 \\
\hline $\mathbf{C l}^{-}\left(250 \mathrm{mg} \mathrm{L}^{-1}\right)$ & 0.99 & \pm 0.02 & 0.86 & \pm & 0.02 \\
\hline $\mathbf{N O}_{2}-\mathbf{N}\left(1 \mathrm{mg} \mathrm{L}^{-1}\right)$ & 1.01 & \pm 0.02 & 0.95 & \pm & 0.09 \\
\hline $\mathrm{CaCO}_{3}\left(13 \mathrm{mg} \mathrm{L}^{-1}\right)$ & 1.04 & \pm 0.02 & 0.88 & \pm & 0.03 \\
\hline $\mathrm{HCO}_{3}^{-}\left(50 \mathrm{mg} \mathrm{L}^{-1}\right)$ & 1.04 & \pm 0.07 & 0.90 & \pm & 0.02 \\
\hline $\mathbf{H P O}_{4}{ }^{2-}\left(10 \mathrm{mg} \mathrm{L}^{-1}\right)$ & 0.95 & \pm 0.03 & 0.86 & \pm & 0.04 \\
\hline \multirow[t]{4}{*}{ D) } & \multicolumn{5}{|c|}{ S OIL DEPLOYMENT } \\
\hline & \multicolumn{2}{|c|}{ Brown Sand } & 0.92 & \pm & 0.09 \\
\hline & \multicolumn{2}{|c|}{ Rendzina } & 0.95 & \pm & 0.08 \\
\hline & \multicolumn{2}{|c|}{ Paddy soil } & 0.93 & \pm & 0.05 \\
\hline
\end{tabular}




\section{REFERENCES}

1- Cassman, K. G. Proc. Natl. Acad. Sci. U. S. A. 1999, 96 (11), 5952-5959.

2- Lawlor, D. W. J. Exp. Bot. 2002, 53 (370), 773-787.

3- Degryse, F.; Smolders, E.; Zhang, H.; Davison, W. Environ. Chem. 2009, 6 (3), 198218.

4- Goulding, K.; Jarvis, S.; Whitmore, A. Philos. Trans. R. Soc. London. Ser. B 2008, 363, 667-680.

5- Cui, S.; Shi, Y.; Groffman, P. M.; Schlesinger, W. H.; Zhu, Y.-G. Proc. Natl. Acad. Sci. U. S. A. 2013, 110 (6), 2052-2057.

6- Strebel, O.; Duynisveld, W. H. M.; Bottcher, J. Agric. Ecosyst. Environ. 1989, 26 (34), 189-214.

7- Puckett, L. J. Environ. Sci. Technol. 1995, 29 (9), 408A - 414A.

8- Gulis, G.; Czompolyova, M.; Cerhan, J. R. Environ. Res. 2002, 88 (3), 182-187.

9- Brinkley, D.; Vitousek, P. In Plant Phisilogical Ecology edited by Pearcy, R.W.; Ehleringer, J.; Mooney, H.A.; Rundel, P.W. pages:75-96; 1991.

10- Stark, J. M.; Hart, S. C. Nature 1997, 385 (6611), 61-64.

11-Linker, R.; Weiner, M.; Shmulevich, I.; Shaviv, A. Biosyst. Eng. 2006, 94 (1), 111118.

12-Zhang, H.; Zhao, F. J.; Sun, B.; Davison, W.; McGrath, S. P. Environ. Sci. Technol. 2001, 35 (12), 2602-2607.

13-Tian, Y.; Wang, X.; Luo, J.; Yu, H.; Zhang, H. Environ. Sci. Technol. 2008, 42 (20), 7649-7654.

14-Davison, W.; Zhang, H. Nature 1994, 237, 546-548.

15- Huang, J.; Bennett, W. W.; Teasdale, P. R.; Gardiner, S.; Welsh, D. T. Anal. Chim. Acta 2016, 923, 74-81.

16-Dočekalová, H.; Diviš, P. Talanta 2005, 65 (5), 1174-1178.

17- Menegario, A. A.; Tonello, P. S.; Durrant, S. F. Anal. Chim. Acta 2010, 683 (1), 107112.

18- Thabano, J. R. E.; Abong’o, D.; Sawula, G. M. J. Chromatogr. A 2004, 1045 (1-2), 153-159.

19-Giblin, A. E.; Laundre, J. A.; Nadelhoffer, K.; Shaver, G. R. Soil Sci. Soc. Am. J. 1994, 58, 1154-1162.

20-Sakadevan, K.; Hedley, M. J.; Mackay, A. D. Aust. J. Soil Res. 1994, 32, 1389-1400.

21-Zhang, H.; Davison, W.; Gadi, R.; Kobayashi, T. Anal. Chim. Acta 1998, 370 (1), 2938.

22-Rowell, D. L. Soil Science: Methods \& Applications; 1994.

23- Ernstberger, H.; Zhang, H.; Tye, A.; Young, S.; Davison, W. Environ. Sci. Technol. 2005, 39 (6), 1591-1597.

24- Tye, A. M.; Young, S. D.; Crout, N. M. J.; Zhang, H.; Preston, S.; Barbosa-Jefferson, V. L.; Davison, W.; McGrath, S. P.; Paton, G. I.; Kilham, K.; Resende, L. Geochim. Cosmochim. Acta 2003, 67 (3), 375-385.

25- Santner, J.; Zhang, H.; Leitner, D.; Schnepf, A.; Prohaska, T.; Puschenreiter, M.; Wenzel, W. W. Environ. Exp. Bot. 2012, 77, 219-226.

26- Williams, P. N.; Santner, J.; Larsen, M.; Lehto, N. J.; Oburger, E.; Wenzel, W.; Glud, R. N.; Davison, W.; Zhang, H. Environ. Sci. Technol. 2014, 48 (15), 8498-8506. 
27- French, M. A.; Zhang, H.; Pates, J. M.; Bryan, S. E.; Wilson, R. C. Anal. Chem. 2005, 77 (1), 135-139.

28- Li, W.; Zhao, H.; Teasdale, P. R.; John, R.; Zhang, S. Anal. Chim. Acta 2002, 464 (2), 331-339.

29- Zhang, H.; Davison, W. Anal. Chem. 1995, 67 (19), 3391-3400.

30- Marx, E. S.; Hart, J.; Stevens, R. G. Soil test interpretation guide; 1999.

31- Mason, S.; Hamon, R.; Nolan, A.; Zhang, H.; Davison, W. Anal. Chem. 2005, 77 (19), 6339-6346.

32- Luo, J.; Zhang, H.; Santner, J.; Davison, W. Anal. Chem. 2010, 82 (21), 8903-8909.

33- Wolt, J. D. Environmental Science and agriculture; 1994.

34- Rosales-Lagarde, L.; Pasten, E.; Mora, A.; Mahlknecht, J. Geophys. Res. Abs. 2016, 18, EGU2016-9784-4.

35- Jones, D.L.; Owen, A.G.; Farrar, J.F. Soil Biol. Biochem. 2002, 34, 1893-1902.

36- Mason, S.; McNeill, A.; McLaughlin, M. J.; Zhang, H. Plant Soil 2010, 337 (1), 243258.

37- Vance, C. P. Plant Physiol. 2001, 127 (2), 390-397.

38- Huang, J.; Bennett, W.W.; Welsh, D.T.; Li, T.; Teasdale, P.R. Anal. Chim. Acta. 2016, 904, 83-91. 